\title{
30. CALCAREOUS DINOFLAGELLATE CYSTS FROM THE LOWER CRETACEOUS OF HOLE 761C, WOMBAT PLATEAU, EASTERN INDIAN OCEAN1
}

\author{
Helmut Keupp ${ }^{2}$
}

\begin{abstract}
Low-diversity calcareous dinoflagellate cysts were studied by SEM in 10 samples from the Lower Cretaceous of Hole 761C (256-235 mbsf). The ?late Aptian/Albian age interval can be recognized because of the calcispheres present. The new orthopithonelloid genus Bitorus is introduced.
\end{abstract}

\section{INTRODUCTION}

The renewal of interest over the past 15 years in Mesozoic calcispheres began with the first extensive SEM documentation of a diverse calcisphere flora isolated from Jurassic and Cretaceous sediments from the Indian Ocean by Bolli (1974). With the exception of a few papers on the ultrastructure of Pithonella (e.g., Andri and Aubry, 1973), this fossil group was previously known mostly from thin sections of limestones. The lack of detailed morphological definition of these smallsized fossils (between 10 and $100 \mu \mathrm{m}$ ) by optical methods produced taxonomic confusion. Descriptions and definitions of the morphologic character became more objective with the aid of the SEM (cf. Villain, 1957, 1977; Keupp, 1981). Keupp $(1979,1980 \mathrm{a}, 1980 \mathrm{~b}, 1987)$ succeeded in proving the peridiniacean affinity of the most prominent representatives of the Mesozoic incertae sedis group Calcisphaerulidae Bonet, 1966, which is closely related to the modern Calciodinellaceae (cf. Wall and Dale, 1968). Fütterer (1976) and Tangen et al. (1982) also proved that the Cenozoic genus Thoracosphaera is of dinoflagellate origin. Calcareous dinoflagellate cysts occurred throughout the world in rock-forming abundance in shelf and slope sedimentary environments during the Jurassic and Cretaceous (Villain, 1981). But despite their importance, calcisphere morphology, paleobiology, and vertical and lateral distribution, as well as environmental aspects, are still poorly understood. The objective of this study of the calcispheres from Ocean Drilling Program (ODP) Leg 122 Hole 761C was to contribute the following:

1. documentation of morphological diversity;

2 . identification of possible environmental (facies) control of calcisphere distribution;

3. biostratigraphic interpretation of the vertical flora succession.

A preliminary outline of the Mesozoic to Cenozoic evolution of the northwestern Australian continental margin, including the development of the Indian Ocean, was reported by von Rad et al. (1989) based on the results of Legs 122 and 123. The site locations of Leg 122 were described and illustrated by von Rad et al. (1989) and von Rad and Thurow (1989). The lithologic sequence at Site 761 is characterized by at least two

\footnotetext{
${ }^{1}$ von Rad, U., Haq, B. U., et al., 1992. Proc. ODP, Sci. Results, 122: College Station, TX (Ocean Drilling Program).

2 Free University Berlin, Institute of Paleontology, Schwendenerstr. 8, D-1000 Berlin, Federal Republic of Germany.
}

hiatuses at the Rhaetian-Liassic/?late Berriasian-Valanginian and the Valanginian/Albian (von Rad and Thurow, this volume). The clastic ferrugineous condensed sandstone section at the base of the Cretaceous sequence contains numerous belemnite guards and represent the rapidly increasing subsidence rate. The light to dark yellowish brown calcisphere-rich nannofossil chalk of the upper Lower Cretaceous (?Valanginian) sediment unit contains six bentonite layers. It seems to have originated under hemipelagic conditions during the juvenile phase of the ocean. The calcareous nannoplankton ooze and chalk of the upper part of the sedimentary column (Albian to Quaternary) represent pelagic conditions during the stage of increasing ocean maturity. The stratigraphic control of the samples is based on calcareous nannoplankton (Bralower, this volume).

\section{MATERIAL AND METHODS}

Twelve samples of Lower Cretaceous light marls and marly chalks from Holes 761B and 761C (Fig. 1) were selected:

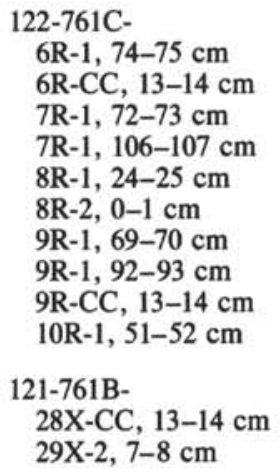

The samples were washed using $20-\mu \mathrm{m}$ mesh sieves. About 100 calcispheres were picked from each sample using a binocular microscope at a magnification of $150 \times$ to $200 \times$ for study by SEM. Neither of the samples from Hole 761B could be used for stratigraphic purposes. The well-cemented limestone of Sample 122-761B-28X-CC, 13-14 cm, contains many calcispheres that are diagenetically completely destroyed. Only few determinable specimens of the stratigraphically wide-ranging morphotype Orthopithonella cf. deflandrei (Kamptner, 1956) were found. The chalky calcisphere packstone of Sample 122-761B-29X-2, 7-8 cm, is also characterized by a monospecific assemblage of Orthopithonella cf. deflandrei. The latter sample appears similar to ?upper Berriasian/Valanginian Samples 122-761C-8R-2, 0-1 cm, and 122761C-9R-CC, $13-14 \mathrm{~cm}$. 


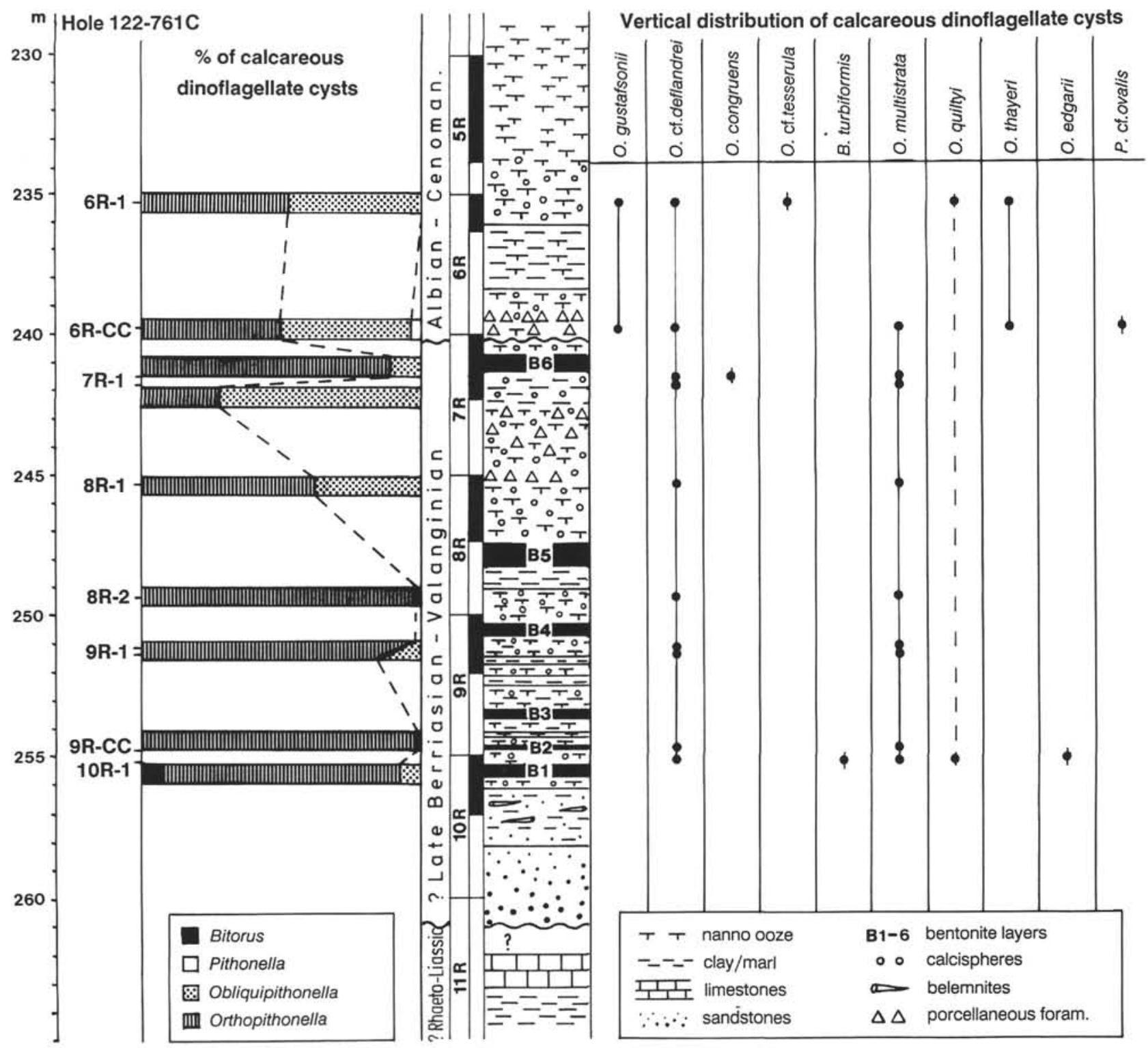

Figure 1. Lower Cretaceous vertical distribution of calcareous dinoflagellate cysts in Hole 761C. Lithologic column and stratigraphy after von Rad and Thurow (this volume).

\section{SYSTEMATIC PALEONTOLOGY}

According to Wall and Dale (1968) and Keupp (1981, 1987), most of the Mesozoic/Cenozoic calcispheres can be classified in the peridinioid cyst family Calciodinelloideae Deflandre, 1947. Fütterer (1976) and Tangen et al. (1982) demonstrated that the modern planktonic calcareous nannoplankton Thoracosphaera heimii represents a vegetative coccoid dinophycean life stage. The cyst family Calciodinelloideae, known from the Upper Triassic (?) and Jurassic to Holocene, is subdivided into three subfamilies based on the orientation of the calcite crystals, which form at least the outer calcareous wall layer (Keupp, 1987). The generally spherical representatives of the calciodinelloideans, which do not exhibit clear morphological paratabulations, have been included in the family Calcisphaerulidae Bonet, 1966 incertae sedis by the former authors. Bolli (1974) named most of these Mesozoic and Cenozoic calcispheres Pithonella Lorenz, 1902. But the different wall structures, each corresponding to paratabulated equivalents, demonstrate that the collective genus Pithonella sensu Bolli, 1974 contains representatives of all the three subfamilies (Keupp and Mutterlose, 1984; Keupp, 1987; Fütterer, 1990). Therefore, generally spherical to elongated calcareous dinoflagellate cysts without morphological modifications caused by specific modes of a paratabulation can be classified with three morphologic genera (Keupp and Mutterlose, 1984; Keupp, 1987): Orthopithonella Keupp, 1984, Obliquipithonella Keupp, 1984, and Pithonella (Lorenz, 1902) Villain, 1975.

Calcareous cysts, which modify their outside morphology mostly by cingular paratabulation patterns (Sarjeant, 1982), are normally classified as separate "genera," despite the 
existence of all intermediate stages between spherical and progressively more well-paratabulated cysts (Keupp, 1981, 1984; Akselman and Keupp, 1990).

The following taxa were isolated from Lower Cretaceous samples from Hole $761 \mathrm{C}$.

Class DINOPHYCEAE Fritsch, 1929

Order PERIDINIALES Haeckel, 1894

Suborder PERIDINIINEAE Fott, 1959 sensu Bujak and Davies, 1983

Family CALCIODINELLACEAE Deflandre, 1947 sensu Bujak and Davies, 1983

Subfamily ORTHOPITHONELLOIDEAE Keupp, 1987

Tribe ORTHOPITHONELLEAE Keupp and Versteegh, 1989

Genus ORTHOPITHONELLA Keupp in Keupp and Mutterlose, 1984

\section{Orthopithonella gustafsonii (Bolli, 1974) \\ (= Pithonella paratabulata Keupp, 1980a) \\ (Pl. 1, Figs. 1-5)}

Remarks. According to the emended species definition given by Willems (1988), the size and morphologic character of this stratigraphically wide-ranging cyst seem to be extremely variable. The size of the spherical to generally ovoid cysts ranges from 20 to $85 \mu \mathrm{m}$, and the thickness of the single-layered calcareous walls ranges from 2 to 12 $\mu \mathrm{m}$ (cf. Willems, 1988). The size and morphology of the archeopyle also vary. The material studied from Leg 122 suggests that there are different morphologically overlapping species in a collective term. In addition, determining the morphological characters is impeded by the diagenetic alteration of the primary structures. The cyst surfaces are commonly modified by solution processes (PI. 1, Figs. 4 and 5) and by neomorphic overgrowth. The radially arranged calcite prisms have been elongated and form more clearly into pinacoid faces. In the investigated material, all transitional morphological stages were found, from cysts with nearly smooth surfaces consisting of subrounded triangular crystals, fairly regular in size, to the morphotypes of Orthopithonella cf. deflandrei (Kamptner, 1956), which are characterized by a rough, more irregular surface structure. Despite the close morphologic affinity between both cyst types, which can prevent their objective separation (particularly of cysts without an archeopyle), the systematic identity of Orthopithonella gustafsonii is acceptable because of the conspicuously differing morphology of the archeopyle. Only those cysts described from the upper Lower Cretaceous (upper Aptian/Albian) have polygonal configurations of archeopyles, due to a cryptotabulate paratabulation mode (Bolli, 1974, pl. 1 , figs. 3 and 9 (holotype), pl. 12, figs. $7-9$ and 12; Keupp, 1980a, pl. 30, figs. 1-6, pl. 31, figs. 1-7; 1981, pl. 9, figs. 1-4 and 7; 1982, pl. $6.2-2$, figs. 7 and $10-11 ; 1987$, pl. 7 , fig. 8). The archeopyle corresponds to one to three apical plate homologues $\left(=2^{\prime}-4^{\prime}\right)$. Unfortunately, Bolli $(1974$, p. 854$)$ in his description of the species postulated circular archeopyles, in contrast to the figures in the same paper. Therefore, stratigraphically older and younger morphotypes with small circular archeopyles have been described as representatives of Orthopithonella gustafsonii by some authors (for example, Keupp and Mutterlose, 1984; Willems, 1988; Fütterer, 1990). It would be better to assign these specimens to other Orthopithonella species. Thus, the relatively thin-walled representatives from the Jurassic/ Lower Cretaceous (cf. Keupp, 1977, 1978) could be classified with "Stomiosphaera" moluccana Wanner, 1940.

These cysts were found only in the samples from Core 122-761C $6 \mathrm{R}$, at 235.75 and $239.98 \mathrm{~m}$ below seafloor (mbsf), in correspondence to the previously described stratigraphic distribution of Orthopithonella gustafsonii sensu stricto in the eastern Indian Ocean (Bolli, 1974) and its similar occurrence in the moderate boreal realm of northwestern Germany.

\section{Orthopithonella cf. deflandrei (Kamptner, 1956)}

$$
\text { (PI. 2, Figs. 1-8, and Pl. 3, Figs. 1-3) }
$$

Remarks. Orthopithonelloid cysts are spherical, with some slightly ovoid, and range in size from 18 to $30 \mu \mathrm{m}$ (Fütterer, 1977b). In the investigated material from Hole $761 \mathrm{C}$, however, they range from 25 to
$58 \mu \mathrm{m}$, with most about $40 \mu \mathrm{m}$. The calcareous wall is composed of a single layer of stockade prisms. The rough distal surface is dominated by enlarged, generally euhedral, trigonal to polygonal crystal faces in a cobblestone-like pattern that resulted from neomorphic overgrowth. The consistently circular archeopyle is small. These cysts are similar to Orthopithonella deflandrei, which was originally reported from the Eocene of France (Kamptner, 1956). Stradner $(1961,1963)$ mentioned a stratigraphic range from Neocomian to Tertiary. The first SEM investigations by Fütterer (1977b) were based Miocene material recovered during Deep Sea Drilling Project (DSDP) Leg 41. Bolli (1974) described a similar cyst about $45 \mu \mathrm{m}$ in diameter from the Upper Cretaceous (DSDP Leg 27) as the holotype of Pithonella johnstonei. With the exception of the larger dimensions, which are analogous to those of the Leg 122 material, the cyst morphology corresponds to that of Orthopithonella deflandrei. Unfortunately, the orthopithonelloid holotype of Pithonella johnstonei (Bolli, 1974, pl. 6, figs. 5-6, pl. 18, fig. 1, and pl. 23, fig. 5) does not correspond to the obliquipithonelloid wall structure described and figured for the broken paratypes (Bolli, 1974, pl. 6, figs. 7-8, and pl. 18, fig. 2). Specimens with only poor indications of neomorphic overgrowth appear similar to Orthopithonella minuta described by Fütterer (1990) from the lower Tertiary of Leg 113. The wide stratigraphic range of similar orthopithonelloid morphotypes, which have few distinguishing morphological characters, allows me to suppose that different real species in one morphospecies that cannot be distinguished morphologically were collected.

The assemblages of orthopithonelloid cysts from Hole 761C, particularly from the pure calcisphere packstones, are dominated by $O$. cf. deflandrei (for example, Samples 122-761C-9R-1, 69-70 cm, and $122-761 \mathrm{C}-8 \mathrm{R}-2,0-1 \mathrm{~cm}$, are more than $99 \%$ calcispheres). Diagenetic processes, such as solution (PI. 3, Figs. 2 and 3) and neomorphism (Pl. 2, Figs. 1 and 3-5), have gradually modified the appearance of the cysts. Small openings over the calcareous wall, as well as the archeopyle, have resulted from diagenesis, partly by pressure solution along points of contact among the densely packed calcispheres within the sediment and partly by calcite displacement due to zeolitic and other cement growth (Pl. 7, Fig. 3). Pflaumann and Krasheninnikov (1978) based the establishment of apparently new calcisphere species ("Pithonella longiporosa," "Pithonella porosa") on similar diagenetically produced phenomena in obliquipithonelloid cysts.

\section{Orthopithonella congruens Fütterer (1990)}

(Pl. 1, Fig. 6)

Remarks. The distal surface of the small spherical cysts, 28 to 30 $\mu \mathrm{m}$ in diameter, is characterized by an extremely regular pattern of calcitic rhombohedrons caused by the regular shape and arrangement of the elongated rhombohedral crystals that have built up the singlelayered wall. The small archeopyle is circular.

This species was originally reported from the upper Maestrichtian and lowermost Danian, but has been found to occur also in Eocene sediments from Jütland/Denmark (Kohring, unpubl. data). Analogous Lower Cretaceous (? Valanginian) specimens were found only in Section 122-761C-7R-1.

\section{Orthopithonella cf. tesserula Fütterer, 1977b}

(PI. 1, Figs. 7, 8)

Remarks. Few small specimens (the cyst diameter is about $28 \mu \mathrm{m}$ ), which were found only in Sample 122-761C-6R-1, 74-75 cm (probably of Albian age), developed tangentially elongated wall crystals that modify the cyst surface and cause partly intermediate morphotypes between Orthopithonella $\mathrm{cf}$. deflandrei and the Cenozoic "Thoracosphaera" tesserula Fütterer, 1977b. This ultrastructural modification analogous to the observations of "Thoracosphaera" saxea Stradner, 1961 made by Fütterer (1977b, p. 716) seems to be strengthened by diagenetic overgrowth. Similar cysts were figured and described by Keupp (1987, p. 51, pl. 18, figs. 1-3) from the Albian of the Boulonnais as possible varieties of Obliquipithonella "carteri" (Bolli, 1974) with extremely coarse wall crystals. But in the Leg 122 material, the orthopithonelloid wall structure characterized by an intercalation of elongated crystal platelets between trigonal prisms (PI. 1, Fig. 8) proves its close relationship with Orthopithonella tesserula. The stratigraphic range of Orthopithonella tesserula, therefore, reaches from the lower Tertiary to the Albian. 

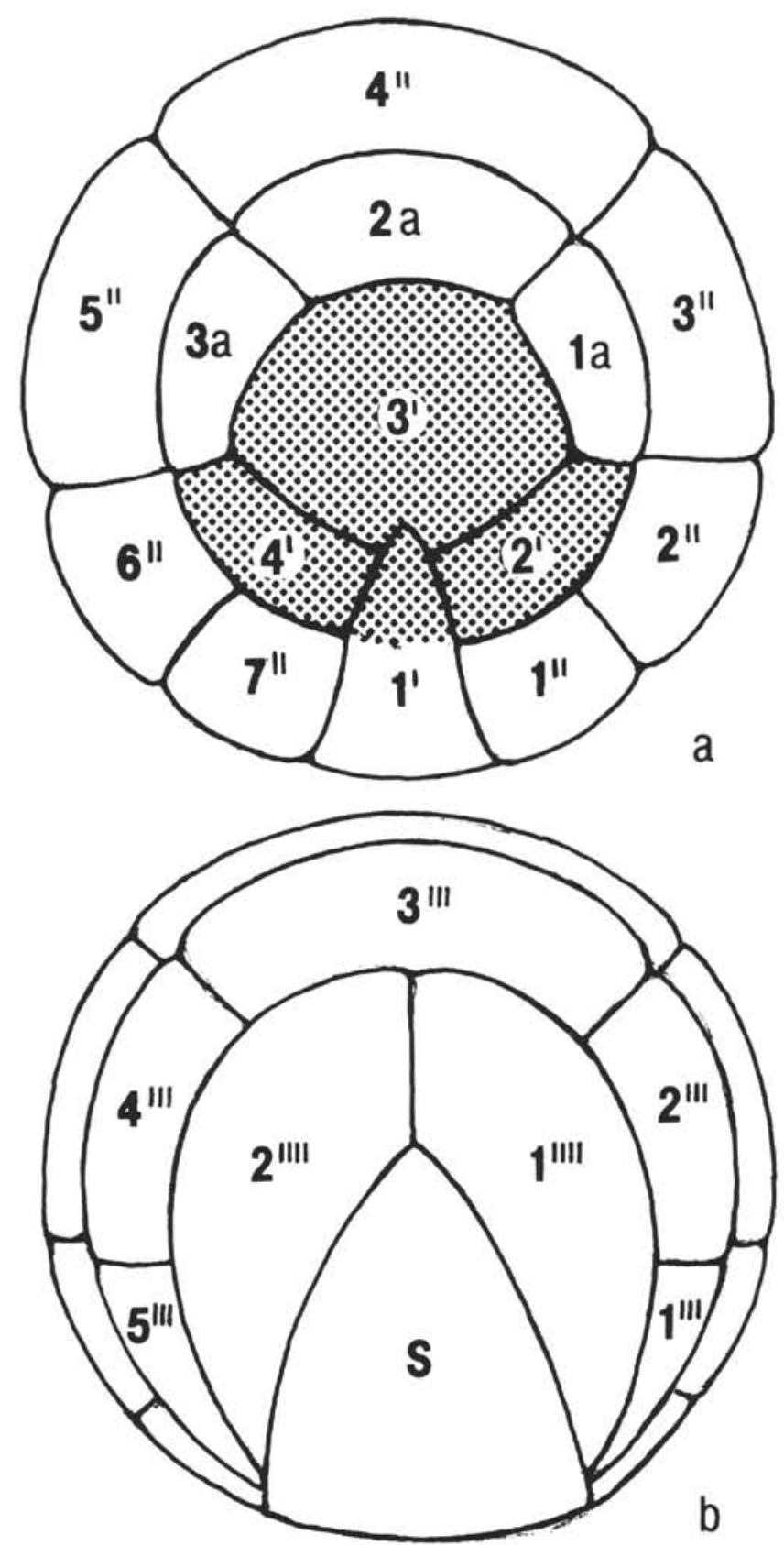

Figure 2. Schematic drawing of the orthoperidinioid paratabulation of Bitorus turbiformis n. gen., n. sp. A. Apical view. Area of archeopyle dotted. B. Antapical view.

Willems (1988) described similar orthopithonelloid cysts from the Upper Cretaceous that are distinguished from the Leg 122 material by more irregular surface structures and a double-layered calcareous wall. He classified these cysts incorrectly (cf. Keupp, 1987; Fütterer, $1990)$ as the obliquipithonelloid species "Bonetocardiella" williambensonii Bolli, 1978a and consequently mentioned this species as belonging to the genus Orthopithonella.

\section{Genus BITORUS n. gen.}

Type species Bitorus turbiformis $\mathrm{n}$. $\mathrm{sp}$.

Diagnosis. The bicarinate orthopithonelloid cysts have a singlelayered calcareous wall. The two prominent circular bulges are equivalent to the precingular and postcingular plates. The apical, conelike operculum ( $=$ archeopyle of exhausted cysts) includes the apical paraplates $2^{\prime}-4^{\prime}$.

Derivation of name. The Latin bi and torus, in reference to the two circular bulges.

Bitorus turbiformis n. sp.

(Fig. 2; Pl. 4, Figs. 1-9, Pl. 5, Figs. 1-7)

Holotype. SEM photographs 122/761C/10R/01-K7 \# 72-74 (cyst 30) (Pl. 4, Figs. 1, 2)

Size. Holotype: height, $58 \mu \mathrm{m}$; width, $71 \mu \mathrm{m}$

Derivation of name. The Latin turbiformis, in reference to the whiplike morphology.

Occurrence. Bitorus turbiformis n. sp. was found only in ?upper Berriasian/Valanginian Sample 122-761C-10R-1, 51-52 cm.

Diagnosis. See the preceding diagnosis of the genus.

Description. The diameter of the cysts ranges from 50 to $72 \mu \mathrm{m}$. The height/width ratio varies from 0.8 to 1.1 , and is typically near 1 . The generally undulating morphology of both of the circular bulges is caused by the incomplete reflection of precingular and postcingular plate equivalents (see Fig. 2 and Pl. 4, Figs. 1-3). The precingular bulge is commonly wider than the postcingular one (PI. 4, Figs. 3 and 8 ). Some of the lower boundaries of the postcingular bulge appear less sharp and the whole hypotract bulges more (Pl. 4, Fig. 5, and Pl. 5, Fig. 2). The eccentric, ventrally shifted conelike operculum, part of which is flattened, corresponds to thecal plates $2^{\prime}-4^{\prime}$. The ventral sulcus is reflected by a smooth groove or a small longitudinal ridge connecting the equatorial bulges (Pl. 5, Figs. 7 and 4, respectively). Instead of the cingulum, a deep intersection appears between the circular bulges (Pl. 4, Figs. 1, 3, 8, and 9). Despite the ventral structure, vertical intersections of the cingular groove reflecting poorly cingular plates were observed in only a few cases. The antapical cone is homologous with the two antapical plates and the antapical sulcus. Its morphology varies from pointed (Pl. 5, Fig. 3) to generally hemispherical. In the case of a clear reflection of the ventral sulcus, the antapical cone was trigonal in its ground plan (PI. 5, Fig. 2). The inner capsule of the cyst is spherical to slightly ovoid. The bicarinate outer cyst morphology arose from the elongation of the radially arranged calcite crystals (PI. 4, Fig. 6).

Differential diagnosis. The new genus exhibits morphological similarities with some species of the obliquipithonelloid genus Bicarinellum Deflandre, 1948, particularly with a new Quaternary species (G. Versteegh, unpubl. data; see also "?Rhodophyceae" sensu Fütterer, 1977a, pl. 24, figs. 1-6) in having such prominent bulges. Among the orthopithonelloid morphotypes, bicarinate cysts are not known yet. The archeopyle corresponding with the apical plate equivalences proves the classification with the tribe Orthopithonelleae Keupp and Versteegh, 1989.

\section{Subfamily OBLIQUIPITHONELLOIDEAE Keupp, 1987}

Genus OBLIQUIPITHONELLA Keupp in Keupp and Mutterlose, 1984

Species group of Obliquipithonella multistrata (Pflaumann and Krasheninnikov, 1978) sensu Keupp, 1981

Obliquipithonella multistrata (Pflaumann and Krasheninnikov, 1978), including "Pithonella carteri" Bolli, 1974

$$
\text { (Pl. 6, Figs. 1-8) }
$$

Remarks. The spherical to ovoid cysts are characterized normally by a double-layered calcareous wall; the outer wall is constructed of one layer of crosslike interfingering calcite crystals. On the surface, the rhombic crystal faces are fairly regular in size and irregularly arranged. The inner wall layer, typically antapically much thicker than near the apex, varies widely in its structure (cf. Keupp, 1981). The exact correspondence of the cysts from Leg 122 to the holotype of "Pithonella carteri" Bolli, 1974 proves their nature as an isolated inner wall layer (PI. 6, Figs. 2, 6). Their surface exhibits irregularly arranged, commonly chevronlike crystal plates. The obvious occurrence of both artificially isolated inner wall layers (cf. also the coarse crystalline equivalent "Pithonella macnightii" [Bolli, 1974]) and cysts that did not develop an original outer calcareous wall (Keupp, 1981, 1984 ) is taxonomically confusing. The first case, which includes the holotype of "Pithonella carteri," contains only fragments of possibly different morphospecies of the Obliquipithonella multistrata group; the second case probably represents separate species. In the material 
studied here, all observed cysts of the "Pithonella carteri" type are only isolated inner wall layers.

In particular, the specimens from Core $122-761 \mathrm{C}-7 \mathrm{R}$ apparently developed a third inner wall layer by diagenetic neomorphism. On the inner cyst surface a regular layer of larger platy crystals grew, in some cases forming a connecting wall of uniform thickness (Pl. 6, Figs. 7 and 8). This pseudowall can be distinguished from a primary biogenetic construction by its immediate overgrowth on the crystal base of the inner wall layer. There are no clear separations due to a primary organic phragm.

The cosmopolitan cysts of Obliquipithonella multistrata have been described from sediments of Middle Jurassic age (Keupp and Ilg, 1989) up to Late Cretaceous (Olsson and Youssefnia, 1979; Willems, 1988). G. Versteegh (unpubl. data) found the same cysts in Mediterranean sediments of the Pliocene-Pleistocene, as well.

Obliquipithonella quiltyi (Bolli, 1974)

(Pl. 7, Figs. 4-5)

Remarks. These morphotypes can be understood as derivatives of Obliquipithonella multistrata with quite elongated crystals in the outer wall layer. The surface of the cysts is irregularly spiny. The phenotype varies widely and independently from the size and length of the crystals. This cosmopolitan species, originally described from the Albian (Bolli, 1974), is known from the Oxfordian to lower Cenomanian (Keupp, 1981, 1987; Keupp and Mutterlose, 1984; Keupp and Ilg, 1989). Only a few specimens were isolated from Samples 122-761C-10R-1, 51-52 cm, and 122-761C-6R-1, 74-75 cm.

\section{Obliquipithonella thayeri (Bolli, 1974)}

$$
\text { (PI. 7, Figs. 7-9) }
$$

Remarks. This common morphotype of Mesozoic rocks was originally described from the Upper Jurassic and is known from the upper Callovian to Cenomanian (Bolli, 1974, 1980; Pflaumann and Krasheninnikov, 1978; Keupp, 1981, 1987; Keupp and Ilg, 1989). But it also occurs in sediments of the Pliocene/Pleistocene (G. Versteegh, unpubl. data). The calcareous wall occurs in both double and single layers and is constructed from different types of calcite crystals. Therefore, the surface is extremely rough and can resemble an agglutinated wall. The irregular cyst habitus has commonly been strengthened by neomorphic enlargement of the primary crystals. This "species" also includes morphotypes described by Bolli (1974) as "Pithonella helentappanae" (see discussions in Keupp, 1981, p. 44; Keupp and Ilg, 1989, pp. 169-170). Specimens with regular rhombohedral overgrowth crystals morphologically approach Obliquipithonella loeblichii (Bolli, 1974) (Pl. 7, Figs. 8, 9). In the material from Hole $761 \mathrm{C}$, typical representatives of this morphotype are restricted to Samples 122-761C-6R-CC, 13-14 cm, and 122-761C$6 \mathrm{R}-1,74-75 \mathrm{~cm}$, which are probably of Albian age.

\section{Obliquipithonella cf. edgarii (Bolli, 1974)}

$$
\text { (PI. 7, Figs. 1, 2) }
$$

Remarks. This morphotype can be interpreted as a special variation of Obliquipithonella thayeri which is characterized by generally platy crystals forming the outer wall layer together with blocky rhombohedrons. The surface structure is dominated by irregularly arranged calcareous laths. The increasing significance of the small crystal plates creates morphologic transitional stages to Obliquipithonella williambensonii (Bolli, 1978b), whereas that of the broad ledges and blocky rhombohedrons leads to Obliquipithonella sheilasantawae (Bolli, 1974). The mostly rudimentary calcified inner wall layer is constructed of more elongated crystals. Due to its subjective synonymy with "Pithonella titanoplax" Rögl, 1976 (Keupp, 1981), the known stratigraphic distribution ranges from Oxfordian to Paleocene (Bolli, 1974, 1978a; Keupp and Mutterlose, 1984, Keupp and Ilg, 1989). Specimens were found only in Sample 122-761C-10R-1, 51-52 $\mathrm{cm}$ (?upper Berriasian/Valanginian; $255.52 \mathrm{mbsf}$ ).

\section{Subfamily PITHONELLOIDEAE Keupp, 1987}

Remarks. Sample 122-761C-6R-CC, 13-14 cm, contains sporadic representatives of the subfamily Pithonelloideae.

Genus PITHONELLA Lorenz, 1902

$$
\text { Pithonella cf. ovalis (Kaufmann, 1865) }
$$$$
\text { (Pl. 3, Figs. 4-7) }
$$

Remarks. The length/width ratio of the ovoid cysts of Pithonella ovalis is 1.12 (length of cysts about $90 \mu \mathrm{m}$ ). Together with the circular transection it demonstrates the transitional position between Pithonella ovalis and Pithonella sphaerica (Kaufmann, 1865) (cf. Villain, 1977; Keupp, 1987). The uniquely oblique orientation of wall crystals produces a regular surface pattern characterized by helicospiral rows of crystals. According to the discussion in Keupp (1987), both longitudinal and helicospiral patterns occur in this species. The stratigraphic distribution of $P$. ovalis (see Bignot and Lezaud, 1964) is worldwide and ranges from the uppermost Aptian to the end of the Maestrichtian (Bignot and Lezaud, 1964; Villain, 1975, 1981; Bolli, 1978a; Keupp, 1987; and many others). Pithonella sphaerica has the same distribution, but has also been reported from Upper Barremian sediments of Speeton, England (Keupp, 1987). Only in open-shelf environments did cysts of Pithonella ovalis/Pithonella sphaerica reach rock-forming abundance (Villain, 1981).

One slightly ovoid specimen $25 \mu \mathrm{m}$ long (PI. 3, Figs. 6 and 7) shows rather regular longitudinal rows of large prismatic crystals. This cyst possibly represents an uncommon variety of Pithonella ovalis with primary large and additional neomorphic wall crystals. On the other hand, similarities exist with Centosphaera barbata Wise and Wind, 1976, which has been reported from the upper Maestrichtian of Leg 113 (Fütterer, 1990). Centosphaera barbata was originally described from the Maestrichtian sediments of Leg 36 as a new thoracosphaeroid nannofossil with prominent keels around it. Due to its morphological character and the occurrence of both exhausted and closed specimens, the affinity to dinoflagellate cysts seems certain. Fütterer (1990) also demonstrated that ovoid cysts about $18-25 \mu \mathrm{m}$ long occur without any keels. The single-layered cyst wall is composed of regularly and tangentially orientated hourglass-shaped to prismatic crystals. The arrangement of these crystals causes regular transverse rows on the cyst surface. The orientation of the crystals corresponds to that of the subfamily Pithonelloideae rather than the Obliquipithonelloideae (cf. Fütterer, 1990; Keupp 1990).

\section{CONCLUSIONS}

The Lower Cretaceous calcisphere flora from Hole $761 \mathrm{C}$ is of a relatively low diversity. The rare occurrence of Pithonella species within the Albian sediments probably resulted from pelagic sedimentation. Most morphotypes of the Orthopithonelloideae and Obliquipithonelloideae are cosmopolitan and occur in a wide stratigraphic range. Only two species can be used as significant stratigraphic markers: Orthopithonella gustafsonii (Bolli, 1974) s. str. and Pithonella cf. ovalis (Kaufmann, 1865).

Both of these cysts characterize the late Aptian to Albian age interval. Therefore, the late Early Cretaceous assignment of the samples from Core 122-761C-6R (235.75 and 239.98 mbsf) is confirmed. The report of Orthopithonella cf. tesserula (Fütterer, 1977b) in Albian sediment samples corresponds to the synchronous first occurrence of this species in Northern France (Keupp, 1987).

\section{ACKNOWLEDGMENTS}

I am indebted to U. von Rad, Hannover, for information about the lithologic and stratigraphic profile and to Heike Bosbach, Berlin, for reading the English text. The Deutsche Forschungsgemeinschaft supported the investigation financially (research project Ke 322/8-1).

\section{REFERENCES}

Akselman, R., and Keupp, H., 1990. Recent obliquipithonelloid calcareous cysts of Scrippsiella patagonica nov. sp. (Peridiniaceae, Dinophyceae) from plankton of the Golfo San Jorge/ Patagonia, Argentina. Mar. Micropaléontol., 16:169-179.

Andri, E., and Aubry, M.-P., 1973. Recherches sur la microstructure des tests de Pithonella ovalis (Kaufmann) et Pithonella perlonga Andri. Rev. Micropaléontol., 16:159-166. 
Bignot, G., and Lezaud, L., 1964. Contribution à l'étude des Pithonella de la Craie Parisienne. Rev. Micropaléontol., 7:138-152.

Bolli, H. M., 1974. Jurassic and Cretaceous Calcisphaerulidae from DSDP Leg 27, eastern Indian Ocean. In Veevers, J. J., Heirtzler, J. R., et al., Init. Repts. DSDP, 27: Washington (U.S. Govt. Printing Office), 843-907.

1978a. Cretaceous and Paleogene Calcisphaerulidae from DSDP Leg 40, Southeastern Atlantic. In Bolli, H. M., Ryan, W.B.F., et al., Init. Repts. DSDP, 40: Washington (U.S. Govt. Printing Office), 819-838.

1978b. Upper Jurassic Calcisphaerulidae from DSDP Leg 44, Site 391C, Blake Bahama Basin, western North Atlantic. In Benson, W. E., Sheridan, R. E., et al., Init. Repts. DSDP, 44: Washington (U.S. Govt. Printing Office), 911-920.

1980. Calcisphaerulidae and Calpionellidae from the Upper Jurassic and Lower Cretaceous of DSDP Hole 416A, Moroccan Basin. In Lancelot, Y., and Winterer, E. L., et al., Init. Repts. DSDP, 50: Washington (U.S. Govt. Printing Office), 525-543.

Bonet, F., 1966. Zonificación microfaunistica de las Calizas Cretácicas del Este de México. XX Congr. Geol. Int. Mexico, 3-102.

Bujak, J. P., and Davies, E. H., 1983. Modern and fossil Peridiniineae. Contrib. Ser. Am. Assoc. Stratigr. Palynol., 13:1-203.

Deflandre, G., 1947. Calciodinellum nov. gen., premier représentant d'une famille nouvelle de Dinoflagellés fossiles à thèque calcaire. C. R. Acad. Sci., 224:1781-1782.

1948. Les Calciodinellidés Dinoflagellés fossiles à thèque calcaire. Botaniste, 34:191-219.

Fott, B., 1959. Algenkunde: Jena (VEB Gustav Fischer).

Fritsch, F. E., 1929. Evolutionary sequence and affinities among the Protophyta. Biol. Rev., 4:103-151.

Fütterer, D., 1976. Kalkige Dinoflagellaten ("Calciodinelloideae") und die systematische Stellung der Thoracosphaeroideae. Neues Jahrb. Geol. Palaeontol. Abh., 151:119-141.

1977a. Die Feinfraktion (Silt) in marinen Sedimenten des ariden Klimabereichs: quantitative Analysenmethoden, Herkunft und Verbreitung: Kiel (Habilitationsschrift). (unpubl.)

1977b. Distribution of calcareous dinoflagellates in Cenozoic sediments of Site 366, eastern North Atlantic. In Lancelot, Y., Seibold, E., et al., Init. Repts. DSDP, 41: Washington (U.S. Govt. Printing Office), 709-737.

1990. Distribution of calcareous dinoflagellates at the Cretaceous-Tertiary boundary of Queen Maud Rise, eastern Weddell Sea Antarctica (ODP Leg 113). In Barker, P. F., Kennett, J. P., et al., Proc. ODP, Sci. Results, 113: College Station, TX (Ocean Drilling Program), 533-538.

Haeckel, E., 1894. Entwurf eines natürlichen Systems der Organismen auf Grund ihrer Stammesgeschichte. Erster Teil: Systematische Phylogenie der Protisten und Pflanzen: Berlin (Georg Reimer).

Kamptner, E., 1956. Thoracosphaera deflandrei nov. spec., ein bemerkenswertes Kalkflagellaten-Gehäuse aus dem Eozän von Donzaq (Dep. Landes, Frankreich). Oesterr. Bot. Z., 103:447456.

Kaufmann, F. J., 1865. Polythalamien des Seewerkalkes. In Heer, O., Die Urwelt der Schweiz: Zürich, 194-199.

Keupp, H., 1977. Ultrafazies und Genese des Solnhofener Plattenkalkes (Oberer Malm, Südliche Frankenalb). Abh. Naturhist. Ges. Nürnberg, 37.

1978. Calcisphaeren des Untertithon der Südlichen Frankenalb und die systematische Stellung von Pithonella Lorenz 1901. Neues Jahrb. Geol. Palaeontol. Monatsh., 1978:87-98.

1979. Lower Cretaceous Calcisphaerulidae and their relationship to calcareous dinoflagellate cysts. Bull. Cent. Rech. Explor.-Prod. Elf-Aquitaine, 3:651-663.

, 1980a. Pithonella paratabulata n. sp., eine unterkretazische Calcisphaere mit äußerer paratabulation. Facies, 3:239-249.

, 1980b. Pithonella patriciacreeleyae Bolli 1974, eine kalkige Dinofalgellaten-Zyste mit interner paratabulation (Unter-Kreide, Speeton/SE-England). Neues Jahrb. Geol. Palaeontol. Monatsh., 1980:513-524.

1981. Die kalkigen Dinoflagellaten-Zysten der borealen UnterKreide (Unter-Hauterivium bis Unter-Albium). Facies, 5:1-190. 1984. Revision der kalkigen Dinoflagellaten-Zysten G. DEFLANDRE's, 1948. Palaeontol. Z., 58:9-31.
1987. Die kalkigen Dinoflagellaten-Zysten des Mittelalb bis Untercenoman von Escalles/Boulonnais (N-Frankreich). Facies, 16:37-88.

1990. Fossil calcareous dinoflagellate cysts. In Riding, R. (Ed.), Calcareous Algae and Stromatolites: Berlin (Springer), 267286.

Keupp, H., and Ilg, A., 1989. Die kalkigen Dinoflagellaten im OberCallovium und Oxfordium der Normandie/Frankreich. Berl. Geowiss. Abh., Reihe A, 106:165-205.

Keupp, H., and Mutterlose, J., 1984. Organismenverteilung in den D-Beds von Speeton (Unterkreide, England) unter besonderer Berücksichtigung der kalkigen Dinoflagellaten-Zysten. Facies, 10:153-178.

Keupp, H., and Versteegh, G., 1989. Ein neues systematisches Konzept für kalkige Dinoflagellaten-Zysten der Subfamilie Orthopithonelloideae Keupp 1987. Berl. Geowiss. Abh., Reihe A, 106:207-219.

Lorenz, T., 1902. Geologische Studien im Grenzgebiete zwischen helvetischer und ostalpiner Fazies. II. Teil: Südlicher Rhaetikon. Ber. Naturforsch. Ges. Freiburg i. Br., 12 (1901):34-62.

Olsson, R. K., and Youssefnia, I., 1979. Cretaceous Calcisphaerulidae from New Jersey. J. Paleontol., 53:1085-1093.

Pflaumann, U., and Krasheninnikov, V. A., 1978. Cretaceous calcisphaerulids from DSDP Leg 41, eastern North Atlantic. In Lancelot, Y., Seibold, E., et al., Init. Repts. DSDP, 41: Washington (U.S. Govt. Printing Office), 817-839.

Rögl, F., 1976. Danian Calcisphaerulidae of DSDP Leg 35, Site 323, southeast Pacific Ocean. In Hollister, C. D., Craddock, C., et al., Init. Repts. DSDP, 35: Washington (U.S. Govt. Printing Office), 701-711.

Sarjeant, W.A.S., 1982. Dinoflagellate cyst terminology: a discussion and proposals. Can. J. Bot., 60:922-945.

Stradner, H., 1961. Vorkommen von Nannofossilien im Mesozoikum und Alttertiär. Erdoel-Z., 77:77-88.

1963. Zur Gliederung des Paläogen im Helvetikum nördlich Salzburg nach planktonischen Foraminiferen. Mitt. Geol. Ges. Wien, 56:1-117.

Tangen, K., Brand, L. E., Blackwelder, P. L., and Guillard, R.R.L., 1982. Thoracosphaera heimii (Lohmann) Kamptner is a dinophyte: observations on its morphology and life cycle. Mar. Micropaleontol., 7:193-212.

Villain, J.-M., 1975. "Calcisphaerulidae” (Incertae sedis) du Crétacé supérieur du Limbourg (Pays-Bas), et d'autres regions. Palaeontographica A, 149:193-242.

1977. Les Calcisphaerulidae: architectures, calcification da la paroi et phylogenese. Palaeontographica A, 159:139-177.

1981. Les Calcisphaerulidae: intérêt stratigraphique et paléoécologique. Cretaceous Res., 2:435-438.

von Rad, U., and Thurow, J., 1989. Vom Tethys-Meer zum Indischen Ozean. Die Geowiss., 7:249-257.

von Rad, U., Thurow, J., Haq, B. U., Gradstein, F., Ludden, J., and ODP Leg 122/123 Shipboard Scientific Parties, 1989. Triassic to Cenozoic evolution of the NW Australian continental margin and the birth of the Indian Ocean (preliminary results of ODP Legs 122 and 123). Geol. Rundsch., 78:1189-1210.

Wall, D., and Dale, B., 1968. Quaternary calcareous dinoflagellates (Calciodinellideae) and their natural affinities. J. Paleontol., 42:1395-1408.

Wanner, J., 1940. Gesteinsbildende Foraminiferen aus Malm und Unterkreide des östlichen Ostindischen Archipels. Nebst Bemerkungen über Orbulinaria Rhumbler und andere verwandte Foraminiferen. Palaeontol. Z., 22:75-99.

Willems, H., 1988. Kalkige Dinoflagellaten-Zysten aus der oberkretazischen Schreibkreide-Fazies N-Deutschlands (Coniac bis Maastricht). Senckenbergiana Lethaea, 68:433-477.

Wise, S. W., Jr., and Wind, F. H., 1977. Mesozoic and Cenozoic calcareous nannofossils recovered by DSDP Leg 36 drilling on the Falkland Plateau, southwest Atlantic sector of the Southern Ocean. In Barker, P., Dalziel, I.W.D., et al., Init. Repts. DSDP, 36: Washington (U.S. Govt. Printing Office), 269-492.

Date of initial receipt: 17 May 1990

Date of acceptance: 25 January 1991

Ms 122B-189 

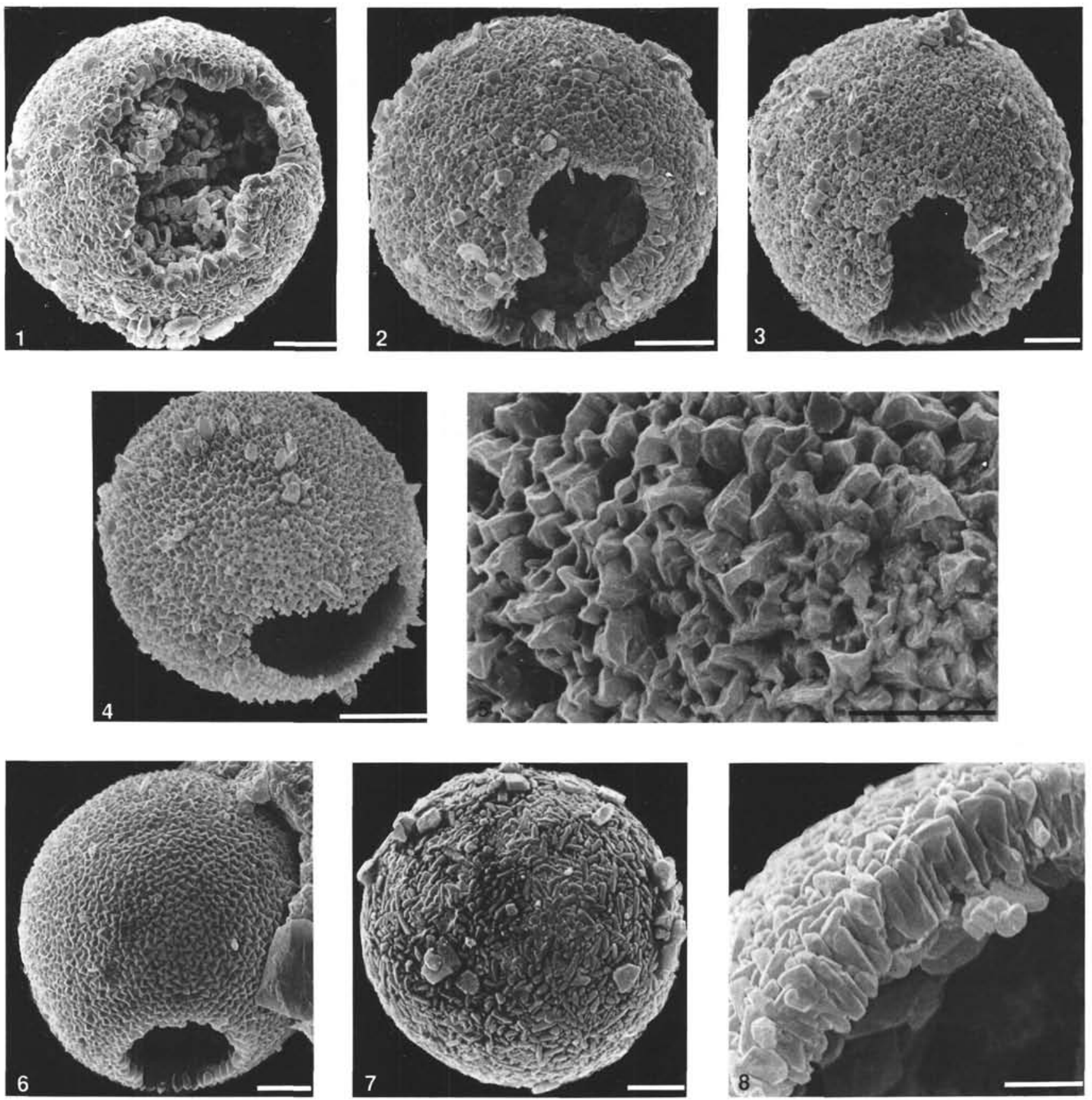

Plate 1. SEM photographs of orthopithonelloid calcareous dinoflagellate cysts from Hole 761C; gun potential $20 \mathrm{kv}$. 1-5. Orthopithonella gustafsonii (Bolli, 1974) of Albian age. (1) The large polygonal archeopyle uses the apical plate equivalences 2'-4', Sample 122-761C-6R-1, $74-75 \mathrm{~cm}$, scale bar $=10 \mu \mathrm{m}$; (2) archeopyle containing only two of the three apical paraplates, Sample $122-761 \mathrm{C}-6 \mathrm{R}-1,74-75 \mathrm{~cm}$, scale bar $=10 \mu \mathrm{m}$; (3) a small suture traces the outline of the third apical plate, Sample 122-761C-6R-1, 74-75 cm, scale bar $=10 \mu \mathrm{m} ;(4,5)$ reduced thickness of wall and irregularly spiny surface patterns as a result of diagenetic solution, Sample $122-761 \mathrm{C}-6 \mathrm{R}-1,74-75 \mathrm{~cm}$, scale bars $=10$ and $5 \mu \mathrm{m}$, respectively. 6. The small cyst of Orthopithonella congruens Fütterer (1990) is characterized by a small circular archeopyle and an extremely regular arrangement of its wall crystals, Sample $122-761 \mathrm{C}-7 \mathrm{R}-1,72-73 \mathrm{~cm}$, ?Valanginian, scale bar $=5 \mu \mathrm{m}$. 7, 8. Orthopithonella cf. tesserula Fütterer, 1977b, Sample 122-761C-6R-1, 74-75 cm, Albian, scale bars $=5 \mu \mathrm{m}$; (7) closed cyst; (8) broken cyst in which the single-layered calcareous wall was constructed by both triangular to hexagonal calcite prisms and elongated, platelike prisms. 

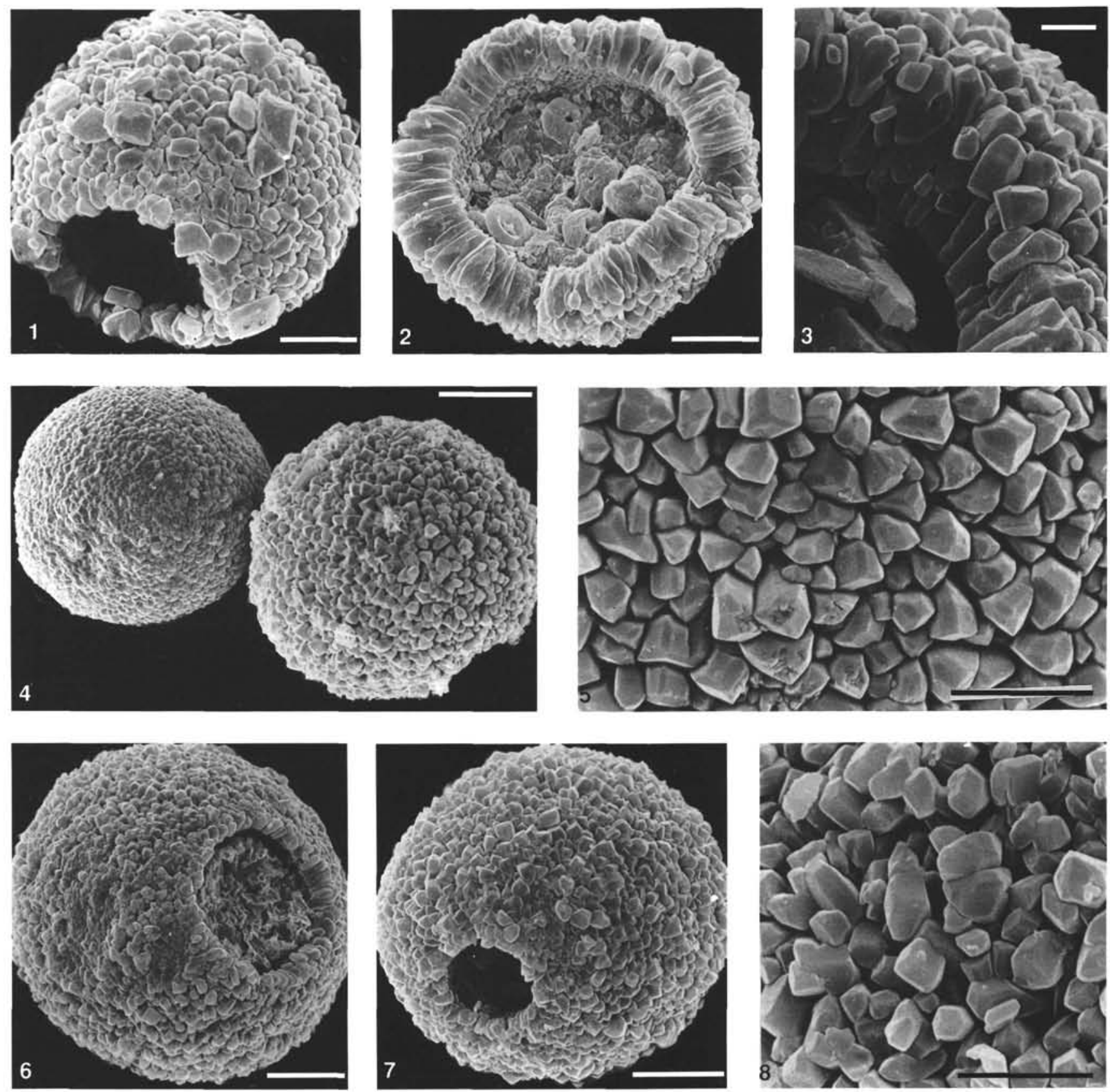

Plate 2. SEM photographs of Orthopithonella cf. deflandrei (Kamptner, 1956) from Holes 761B and 761C, characterized by small circular archeopyles; gun potential $20 \mathrm{kv}$. 1. Specimen with coarse crystals, Sample 122-761C-6R-CC, 13-14 cm, Albian, scale bar = $5 \mu \mathrm{m} .2$. Broken cyst exhibiting the relatively thick wall composed by one layer of radially arranged calcite prisms, Sample 122-761C-7R-1, 106-107 $\mathrm{cm}$, ?Valanginian, scale bar $=10 \mu \mathrm{m}$. 3. Archeopyle margin with distal crystal faces resulting from neomorphism, Sample 122-761C-9R-1, 92-93 cm, ?upper Berriasian/Valanginian, scale bar $=2 \mu \mathrm{m} .4$, 5. Sample 122-761B-29X-2, 7-8 cm, Lower Cretaceous; (4) two cysts that exhibit different preservation stages: the back specimen is nearly without neomorphism, the other has an irregular surface pattern owing to increasing diagenetic overgrowth, scale bar $=10 \mu \mathrm{m} ;(5)$ another cyst showing the neomorphic, irregular arrangement with numerous intercrystalline spaces of the distal crystal faces, scale bar $=5 \mu \mathrm{m}$. 6. Open cyst with larger but also circular archeopyle, Sample 122-761C-9R-1, 69-70 cm, ?upper Berriasian/Valanginian, scale bar $=10 \mu \mathrm{m}$. 7. Open cyst with small circular archeopyle, Sample $122-761 \mathrm{C}-7 \mathrm{R}-1,106-107 \mathrm{~cm}$, probably Valanginian, scale bar $=10 \mu \mathrm{m}$. 8. Cyst surface showing an irregular pattern of neomorphic distal crystal faces, Sample 122-761C-9R-1, 69-70 cm, ?upper Berriasian/Valanginian, scale bar $=5 \mu \mathrm{m}$. 

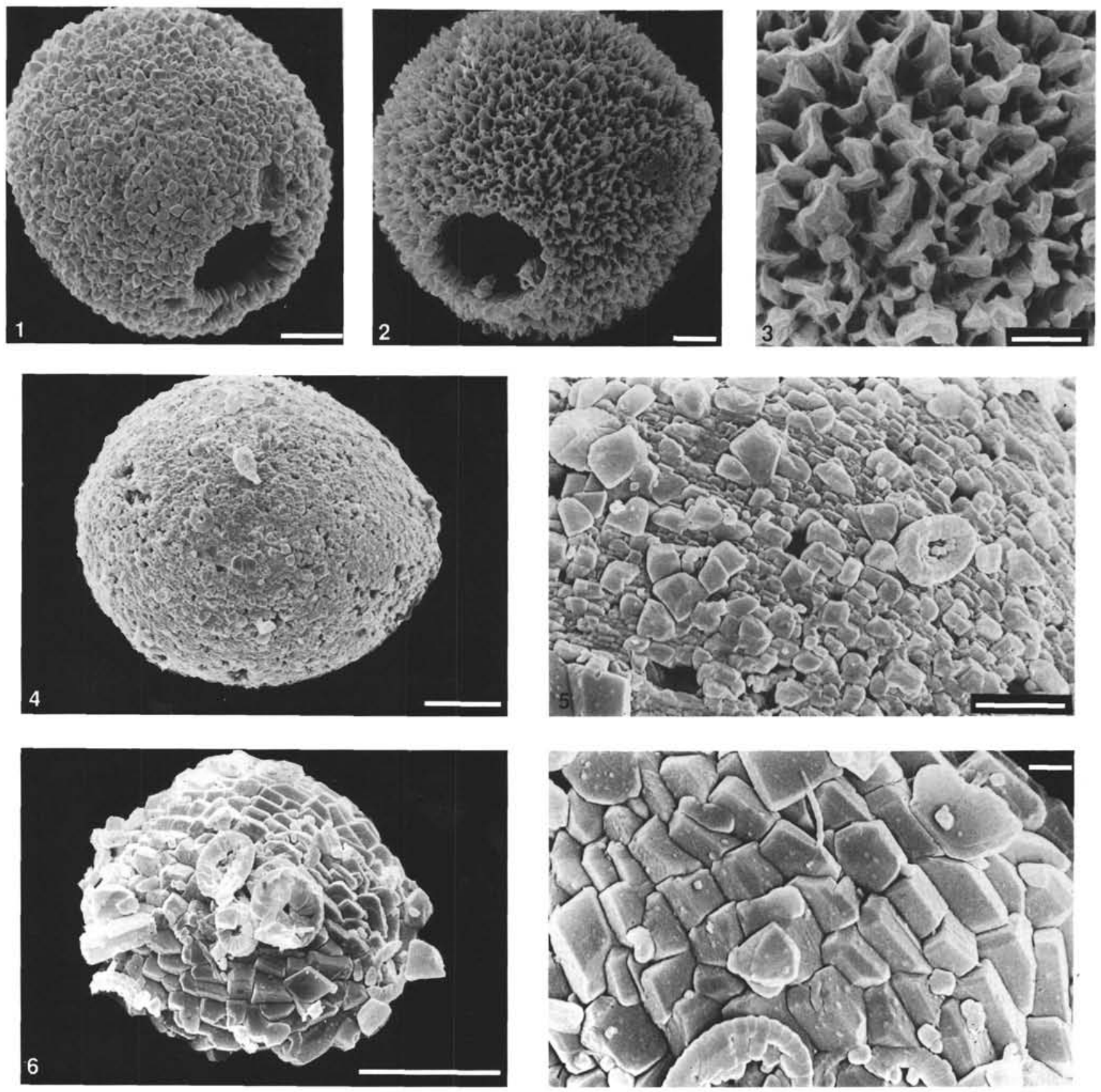

Plate 3. SEM photographs of orthopithonelloid and pithonelloid calcareous dinoflagellate cysts from Hole $761 \mathrm{C}$; gun potential $20 \mathrm{kv}$. 1-3. Orthopithonella cf. deflandrei (Kamptner, 1956); (1) slightly ovoid cyst, Sample 122-761C-8R-2, 0-1 cm, Valanginian, scale bar $=10 \mu \mathrm{m} ;(2,3)$ specimen that seems spiny because of diagenetic solution and closeup view of the surface, Sample 122-761C-9R-CC, 13-14 cm, upper Berriasian/Valanginian, scale bars $=5$ and $2 \mu \mathrm{m}$, respectively. 4-7. Pithonella cf. ovalis (Kaufmann, 1865), Sample 122-761C-6R-CC, $13-14 \mathrm{~cm}$, Albian; $(4,5)$ the only slightly ovoid cyst in the morphologic range between $P$. sphaerica (Kaufmann, $1865)$ and $P$. ovalis (Kaufmann, 1865) and a closeup view of the regular, slightly helicospiral arrangement of crystal rows on the surface, scale bars $=20$ and $5 \mu \mathrm{m}$, respectively; $(6,7)$ the large prismatic crystals of the cyst $(25 \mu \mathrm{m}$ in length), which posses probable affinities with unkeeled specimens of Centosphaera barbata Wise and Wind, 1976 reported by Fütterer (1990), are arranged in regular longitudinal rows, scale bars $=10$ and $2 \mu \mathrm{m}$, respectively. 

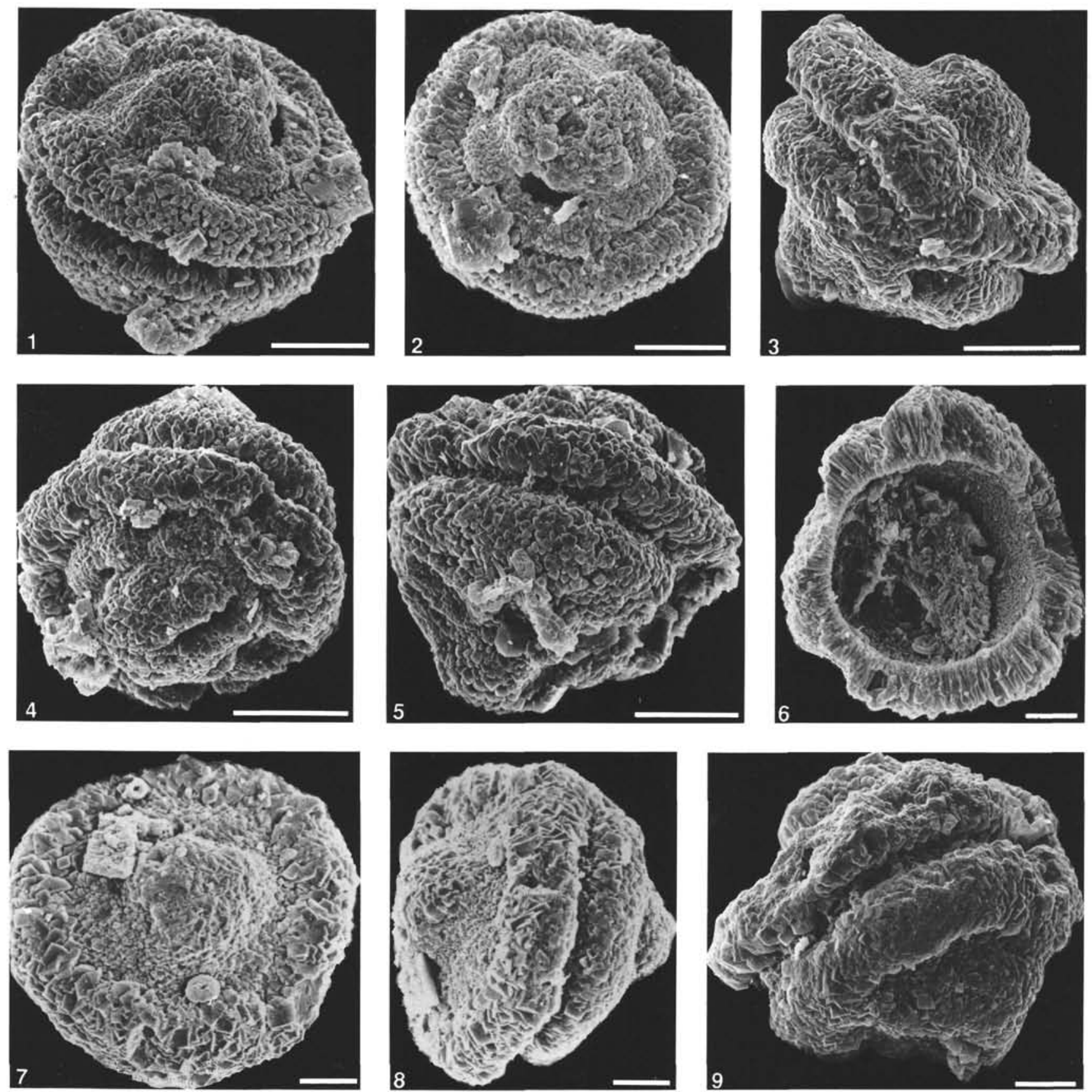

Plate 4. SEM photographs of the new orthopithonelloid calcareous dinoflagellate cyst Bitorus turbiformis n. gen., n. sp., Sample 122-761C-10R-1, 51-52 cm, ?upper Berriasian/Valanginian; gun potential $20 \mathrm{kv}$. 1, 2. Holotype: closed cyst, scale bars $=20 \mu \mathrm{m}$; (1) lateral-apical view; (2) apical view. 3. Ventral view of a closed cyst and the two circular bulges that represent the homologues of the precingular and postcingular plates, scale $b a r=20 \mu \mathrm{m} .4,5$. The postcingular bulge of this closed cyst specimen appears less prominent which causes the hypotract to be rather conical, scale bars $=20 \mu \mathrm{m}$; (4) apical view; (5) lateral view. 6. The single-layered radial-fibrous calcareous wall is visible in a broken cyst enclosing a spherical organic capsule, scale bar $=10 \mu \mathrm{m} .7,8$. In contrast to the holotype, the apical area of this closed cyst does not reflect any thecal plate equivalences, scale bars $=10 \mu \mathrm{m}$; (7) apical view; (8) lateral view. 9. Lateral view of a closed cyst in which the conical antapex is flattened by the broad sulcus, scale bar $=10 \mu \mathrm{m}$. 

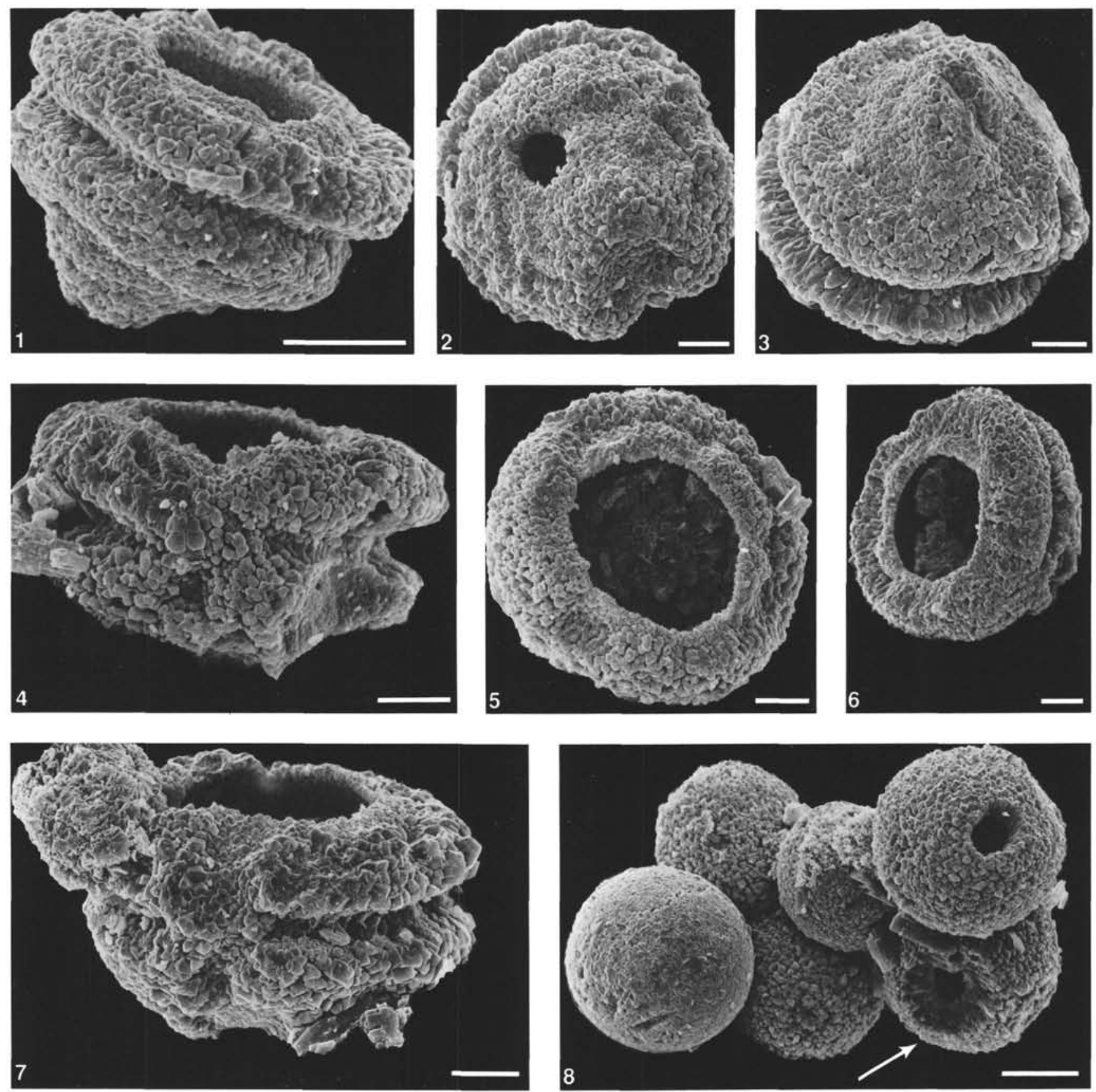

Plate 5. SEM photographs of calcareous dinoflagellate cysts from Hole 761C; gun potential 20 kv. 1-7. Bitorus turbiformis n. gen., n. sp., Sample 122-761C-10R-1, 51-52 cm, ?upper Berriasian/Valanginian); (1) in dorsal view, the open cyst resembles a top because of the near correspondence in diameter of both the precingular and postcingular bulges, scale bar $=20 \mu \mathrm{m}$; (2) the antapical sulcus of this specimen is reflected by a trigonal area dominating the hypocyst in antapical view (the small opening is caused by microborers), scale bar $=10 \mu \mathrm{m}$; (3) cyst with a pointed antapex, scale bar $=10 \mu \mathrm{m}$; (4) ventral view of an open cyst in which the ventral sulcus connects both transverse bulges by a longitudinal ridge, scale bar $=10 \mu \mathrm{m}$; (5) the three small bulges in this apical view of an exhausted cyst, which are positioned dorsally of the large archeopyle, correspond with the equivalences of the intercalary plates, scale bar $=10 \mu \mathrm{m} ;(6)$ a similar cyst in apical-ventral view, scale bar $=10 \mu \mathrm{m}$; (7) ventral view of an exhausted cyst in which the ventral sulcus of this specimen is reflected as a broad furrow, scale bar $=10 \mu \mathrm{m}$. 8. Densely packed calcareous dinoflagellate cysts within the ?upper Berriasian/Valanginian "calcisphere packstone" have artificial openings (arrow) created by pressure solution, Sample 122-761C-9R-1, 92-93 cm, scale bar $=20 \mu \mathrm{m}$. 

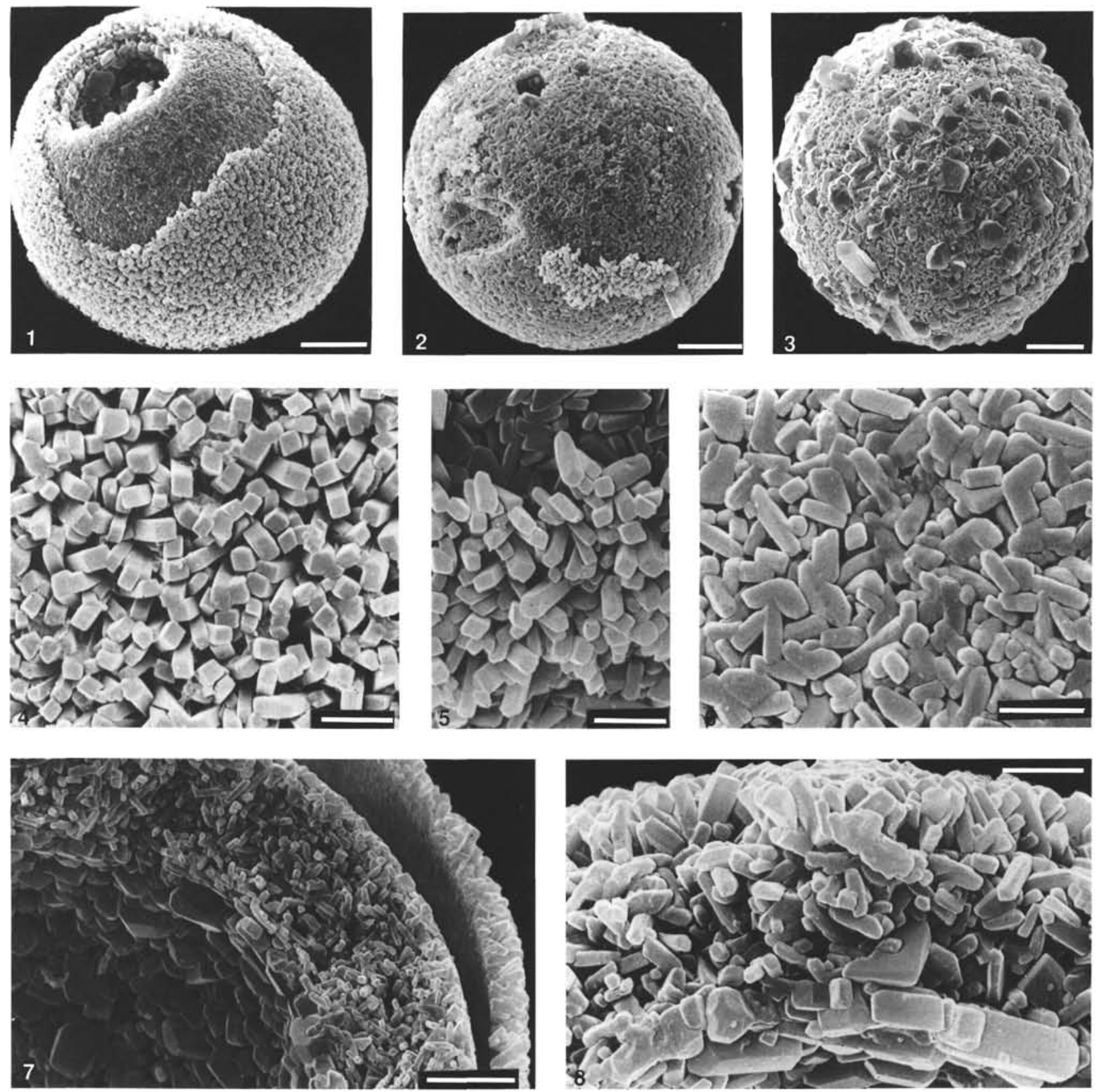

Plate 6. SEM photographs of Obliquipithonella multistrata (Pflaumann and Krasheninnikov, 1978) from Hole 761C; gun potential 20 kv. 1, 4. Sample 122-761C-7R-1, 106-107 cm, ?Valanginian; (1) the thin outer wall layer composed of irregularly arranged, elongated calcite rhombohedrons in this exhausted cyst was partly lost, scale bar $=10 \mu \mathrm{m}$; (4) surface detail from a similar specimen, scale bar $=2 \mu \mathrm{m}$. 2, 5. Sample 122-761C-9R-CC, 13-14 cm, ?upper Berriasian/Valanginian; (2) nearly complete loss of the outer wall layer by artificial means, scale bar $=10 \mu \mathrm{m}$; (5) detail of the surface of both wall layers, scale bar $=2 \mu \mathrm{m}$. 3. Isolated inner calcareous wall layer diagenetically modified by intercalations of larger calcite crystals, Sample 122-761C-9R-1, 92-93 cm, ?upper Berriasian/Valanginian, scale $\mathrm{bar}=10 \mu \mathrm{m}$. 6. The artificially completely isolated inner calcareous wall layers of Obliquipithonella multistrata correspond exactly to the "Pithonella carter"' holotype described by Bolli (1974) from the Tithonian of Leg 27, Sample 122-761C-9R-1, 92-93 cm, ?upper Berriasian/Valanginian, scale bar $2 \mu \mathrm{m} .7,8$. The originally double-layered calcareous wall seems triple layered in some samples as a result of the diagenetic growth of a generally connected layer of larger cement crystals inside the inner wall layer, as shown in two broken cysts, Sample 122-761C-7R-1, 106-107 cm, ?Valanginian, scale bars $=5$ and $2 \mu \mathrm{m}$, respectively. 

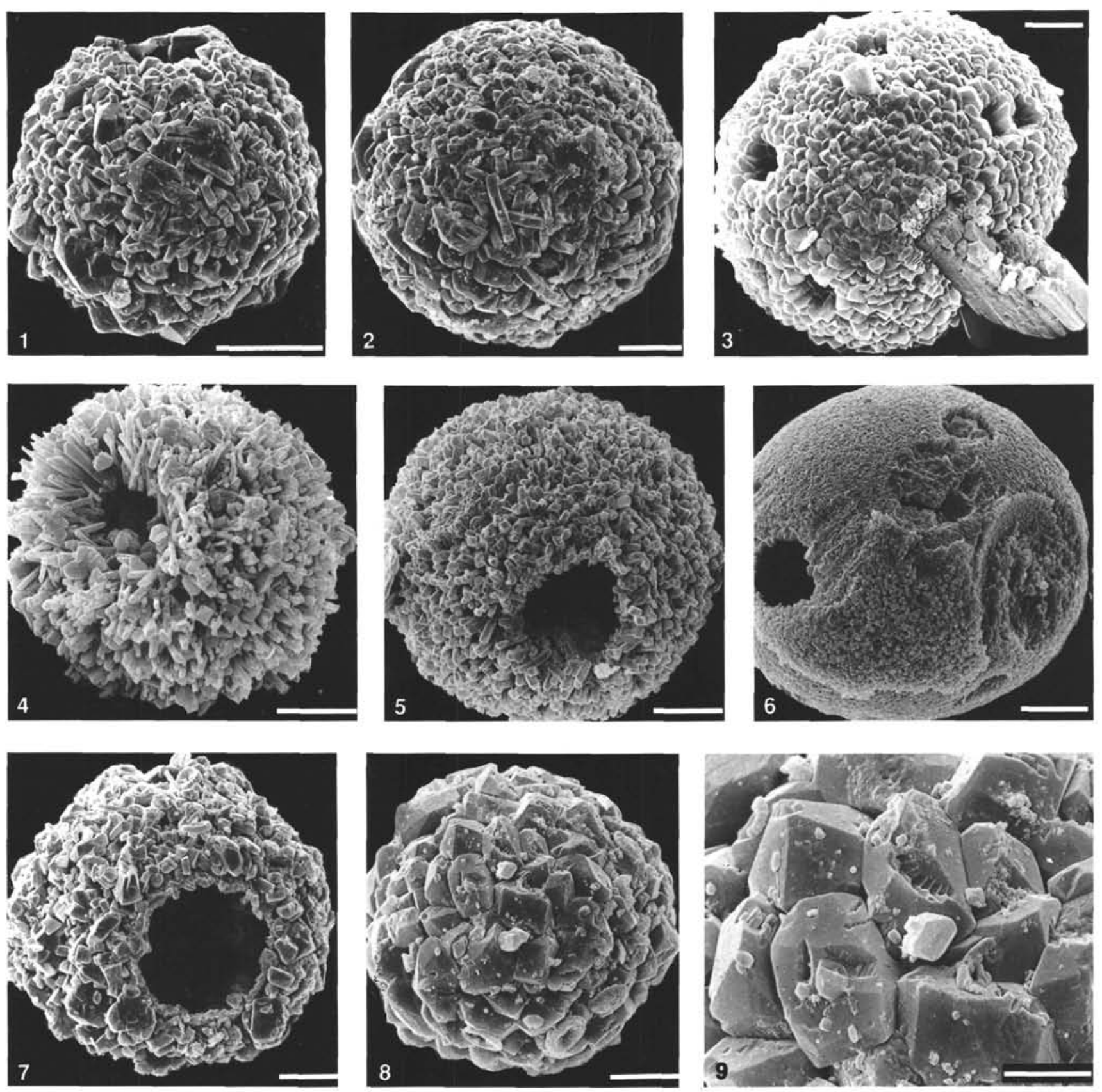

Plate 7. SEM photographs of dinoflagellate cysts from Hole 761C; gun potential $20 \mathrm{kv.} \mathrm{1,} \mathrm{2.} \mathrm{Obliquipithonella} \mathrm{cf.} \mathrm{edgarii} \mathrm{(Bolli,} \mathrm{1974),}$ Sample 122-761C-10R-1, 51-52 cm, ?upper Berriasian/Valanginian; (1) exhausted cyst, scale bar $=20 \mu \mathrm{m} ;(2)$ closed cyst, scale bar $=10$ $\mu \mathrm{m}$. 3. Orthopithonella $\mathrm{cf}$. deflandrei with many small pores caused by calcite displacement due to zeolitic cement growth, Sample 122-761C-7R-1, 106-107 cm, ?Valanginian, scale bar $=5 \mu \mathrm{m} .4,5$. Obliquipithonella quiltyi (Bolli, 1974) derives from the $O$. multistrata group sensu Keupp, 1981 through the strong elongation of the outer wall crystals, scale bars $=10 \mu \mathrm{m}$; (4) Sample 122-761C-6R-1, 74-75 $\mathrm{cm}$, Albian; (5) Sample 122-761C-10R-1, 51-52 cm, ?upper Berriasian/Valanginian. 6. Obliquipithonella multistrata (Pflaumann and Krasheninnikov, 1978) with a fragment of another calcisphere countersunk in its wall by pressure solution, Sample 122-761C-7R-1, 72-73 $\mathrm{cm}$, ?Valanginian, scale bar $=10 \mu \mathrm{m}$. 7-9. Obliquipithonella thayeri (Bolli, 1974); (7) exhausted cyst, Sample 122-761C-6R-CC, 13-14 cm, Albian, scale bar $=10 \mu \mathrm{m} ;(8,9)$ the neomorphic overgrowth creates cysts with rough surfaces similar to that of the Obliquipithonella loeblichii group sensu Keupp, 1981, but the diagenetic character of the large crystals is proven by the inclusion of coccoliths from the surrounding sediment, Sample 122-761C-6R-1, 74-75 cm, Albian, scale bars $=10$ and $5 \mu \mathrm{m}$, respectively. 